\title{
PENERAPAN TEKNOLOGI REPRODUKSI INSEMINASI BUATAN UNTUK MENINGKATKAN PRODUKTIVITAS REPRODUKSI DAN PEMBERDAYAAN PETERNAK ITIK DI KECAMATAN CANDI KABUPATEN SIDOARJO \\ REPRODUCTIVE TECHNOLOGY IMPLEMENTATION OF ARTIFICIAL INSEMINATION TO IMPROVING REPRODUCTION PRODUCTIVITY AND EMPOWERMENT OF DUCK FARMERS IN CANDI SUB-DISTRICT SIDOARJO
}

\author{
Rosa Tri Hertamawati ${ }^{\# 1}$ dan Epy Muhammad Luqman ${ }^{* 2}$ \\ \#Program Studi Manajemen Bisnis Unggas, Jurusan Peternakan, Politeknik Negeri Jember \\ Jalan Mastrip 164 Jember \\ ${ }^{1}$ rosa_trihertamawati epolije.ac.id \\ *Departemen Embriologi, Fakultas Kedokteran Hewan, Universitas Airlangga \\ Surabaya \\ epy_mLuqman@unair.ac.id
}

\begin{abstract}
Abstrak
Kecamatan Candi di Kabupaten Sidoarjo merupakan sentra produksi telur itik yang memerlukan diversifikasi usaha untuk mengatisipasi harga pasar telur itik tidak stabil.Usaha pembibitan melalui teknologi Inseminasi Buatan (IB) merupakan salah satu diversifikasi produkuntuk menghasilkan telur tetas sebagai upaya untuk menghasilkan DOD yang mempunyai daya tetas tinggi dan meningkatkan efisiensi pejantan. Pengabdian masyarakat ini dilaksanakan di Kecamatan Candi Kebupaten Sidoarjo selama 2 bulan yang terbagi dalam dua tahap yaitu : Pada tahap I dilakukan interview dan wawancara ntuk mengetahui latar belakang pengetahuan, minat dan kemampuan dalam para peternak inseminasi buatan pada itik.Pada tahap IIdiberikan pelatihanpada peternak dan mengevaluasi pengetahuan dan kemampuan secara teoritis dalam inseminasi buatan pada itik. Evaluasi untuk mengetahui kemampuan dan minat peternak, evaluasi ini dilakukan selama kegiatan berupa kuisioner untuk pre dan post test. Pemberdayaan melalui penyuluhan dan pelatihan telah mampu meningkatkan pengetahuan dan kemampuan peternak itik di Kelompok Peternak Itik sebesar 14,74\% dan sebagian besar peternak itik $(\mathbf{7 3 , 6 8} \%)$ berminat menerapkan teknologi IB pada itik sebagai upaya efisiensi penggunaan pejantan itik, meningkatkan fertilitas dan daya serta kualitas anak itik dalam rangka meningkatkan pendapatan.
\end{abstract}

Kata Kunci —Itik, Inseminasi Buatan (IB), teknologi reproduksi, pemberdayaan peternak

Abstract

Candi Subdistrict in Sidoarjo Regency is a duck egg production center which requires diversification of efforts to anticipate the unstable market price of duck eggs. Breeding efforts through Artificial Insemination (IB) technology is one of the diversification of products to produce hatching eggs as an effort to produce DOD which has high hatchability. and improve stud efficiency. This community service was carried out in Candi District, Sidoarjo Regency for $\mathbf{2}$ months, which was divided into two stages, namely: In stage I, interviews and interviews were conducted to understand the background knowledge, interest and ability of breeders of artificial insemination in ducks. In stage II, it was given training on breeders and evaluating their theoretical knowledge and abilities in artificial insemination in ducks. Evaluation to determine the ability and interest of breeders, this evaluation was carried out during the activity in the form of a questionnaire for pre and post test. Empowerment through counseling and training has been able to increase the knowledge and ability of duck breeders in the Duck Farmer Group by $\mathbf{1 4 . 7 4 \%}$ and most of the duck breeders $\mathbf{7 3 . 6 8 \%}$ ) are interested in applying IB technology to ducks as an effort to efficiently use male ducks, increase fertility and power. as well as the quality of ducklings in order to increase income.

Keywords — Ducks, Artificial Insemination (IB), reproductive technology, farmer empowerment

\section{PENDAHULUAN}

Peningkatan populasi dan produktivitas ternak itik tergantung pada keberhasilan induk untuk menghasilkan telur dengan daya tetas yang tinggi dalam satu siklus produksi. Namun demikian disadari bahwa produktivitas itik lokal masih rendah, sehingga perlu meningkatkan mutu genetik ternak yang didukung oleh penelitian [1] Setioko (2012) yang menyatakan bahwa untuk meningkatkan produktivitas itik perlu dilakukan perbaikan mutu genetik bibit induk ,sosialisasi teknologi IB kepada 
petani dan pembentukan penangkar bibit yang profesional di sentra produksi itik potong tersebut.

Inseminasi buatan (IB) adalah suatu teknik atau cara pemindahan cairan reproduksi jantan (semen) ke dalam alat reproduksi betina dengan cara buatan [2] (Toelihere, 1979; [3] Hafez, 1983). Inseminasi Buatan pada unggas merupakan satu teknik yang sangat berguna pada unggas baik untuk pengembangan industri perunggasan maupun untuk penelitian-penelitian ilmiah. Progam pemuliaan unggas dan studi lainnya dapat dilakukan secara efektif dan efisien dengan menggunakan teknik IB. Teknologi IB pada itik dikembangkan pertama kali di negara Jepang dan China [4] dan [5].

Kecamatan Candi di Kabupaten Sidoarjo Jawa Timur merupakan daerah sentra itik dengan jumlah populasi total 10 ribu ekor itik. Hampir semua penduduk di desa ini beternak itik baik dalam skala kecil sampai besar, rata-rata setiap kepala rumah tangga memelihara 250-3000 ekor itik sebagai usaha utama maupun sambilan dengan tujuan untuk menghasilkan telur, sebagaimana dilaporkan oleh [6] bahwa jumlah rumah tangga yang terlibat dalam usaha peternakan itik di Indonesia saat ini adalah 285.000 atau $6,34 \%$ dari total rumah tangga peternak. Ternak itik yang diusahakan adalah jenis itik lokal (Mojosari) yang dipelihara secara intensif (dikandangkan) yang disebut juga dengan pemeliharaan kering. Deskripsi produksi itik Mojosari yang digunakan peternak adalah bibit itik siap telur (umur sekitar 6 bulan) dilakukan dengan cara membeli dari luar, tingkat produktivitas itik bertelur sekitar 65 - 70 persen / tahun / ekor dan umur itik afkir sekitar 18 bulan.

Sebagian besar peternak tidak mengenal usaha pembibitan itik untuk menghasilkan DOD (Day Old Duck) dan itik jantan sebagai itik pedaging. Oleh sebab itu perlu dilakukan pemberdayaan melalui diversifikasi usaha selain menghasilkan telur itik konsumsi yaitu usaha pembibitan untuk menghasilkan DOD dan itik pedaging. Hal ini perlu dilakukan untuk mengatisipasi harga pasar telur itik tidak stabil/jatuh sehingga peternak masih dapat mengharapkan pendapatan dari usaha pembibitan. Untuk menghasilkan DOD yang mempunyai daya tetas tinggi dan meningkatkan efisiensi pejantan maka perlu menggunakan metode Inseminasi Buatan (IB). IB pada itik relatif muda dilaksanakan dan tidak memerlukan keahlian khusus, hanya dengan kesabaran dan ketekunan dalam menampung sperma itik jantan sudah dapat memberikan hasil yang optimal. Pemberdayaan peternak melalui penerapan IB pada itik diharapkan akan bermanfaat untuk mengefisienkan pemeliharaan pejantan dan meningkatkan fertilitas telur tetas sehingga produktivitas ternak itik pun akan meningkat.

\section{TARGET DAN LUARAN}

Target dari kegiatan pengabdian masyarakat ini adalah memperkenalkan teknologi inseminasi buatan pada itik dalam rangka meningkatkan produktivitas itik dan memperbaiki kinerja reproduksi itik dalam hal meningkatkan daya tetas dan efisiensi penggunaan pejantan serta meningkatkan pengetahuan dan ketrampilan peternak itik dalam pemanfaatan teknologi inseminasi buatan dengan teknik yang benar untuk memperbaiki kinerja reproduksi itik yang lebih baik.

Manfaat yang diperoleh peternak itik dengan program Inseminasi Buatan ini adalah meningkatkan efisiensi pemeliharaan itik dengan jumlah pejantan lebih sedikit dan meningkatkan kualitas itik betina dan fertilitas telur dengan menghasilkan daya tetas yang tinggi.

Luaran dari kegiatan ini adalah peningkatan pengetahuan dan ketrampilan peternak itik, video pelaksanaan IB pada itik dan publikasi melalui seminar nasional.

\section{METODE PELAKSANAAN}

Pengabdian masyarakat ini dilaksanakan di Kecamatan Candi Kebupaten Sidoarjo selama 2 bulan. Sebanyak 30 orang anggota peternak diikutsertakan dalam pelatihan inseminasi buatan pada itik. Pengabdian masyarakat ini dilakukan dalam dua tahap yaitu : Tahap I. Untuk menge $\neg$ ta $\neg$ hui latar belakang pengetahuan, minat dan kemampuan dalam inseminasi buatan pada itik yang dilakukan dengan cara interview / wawancara kepada para peternak yang terpilih untuk dikutsertakan dalam pengabdian masyarakat ini.

Tahap II . Tahap memberi pelatihan pada peternak dan mengevaluasi pengetahuan dan kemampuan secara teoritis dalam inseminasi buatan pada itik. Materi pelatihan ini meliputi manajemen beternak itik dan inseminasi buatan pada itik. Disamping materi yang disampaikan pada saat pelatihan, peternak juga akan diberikan buku panduan dari materi yang diberikan, dengan demikian peternak dapat membaca kembali materi yang telah diberikan oleh Tim Pengabdian Kepada Masyarakat. Dalam pelatihan ini juga dilakukan peragaan dan pengenalan alat-alat IB sederhana yang akan digunakan. Pada tahap ini dilakukan praktek pengambilan semen, membuat larutan pengencer semen dan cara melakukan IB pada itik betina. Pelatihan dilakukan pada pagi hari $(09.00-12.00)$ setelah betina bertelur dan peternak memberi pakan.

Evaluasi untuk mengetahui kemampuan dan minat peternak, evaluasi ini dilakukan selama kegiatan berupa kuisioner untuk pre dan post test yang segera dianalisis oleh Tim Pengabdian Kepada Masyarakat. Kuisioner untuk pre dan post test merupakan sarana untuk mengukur kemampuan peternak dalam pengolahan pakan ternak untuk 
penggemukan sapi potong. Substansi pertanyaan kuisioner untuk pre dan post test adalah sama, dengan demikian akan diketahui pertambahan tingkat kemampuan peternak setelah dilakukan pelatihan. Evaluasi ini dapat diketahui pula : respon peternak terhadap penyuluhan tentang teknologi IB pada itik, hasil pelatihan dan ketrampilan peternak yang diberi pelatihan tentang IB itik dan kemauan peternak dalam menerapkan IB untuk meningkatkan kinerja reproduksi pada ternak itik.

\section{HASIL DAN LUARAN YANG DICAPAI}

Pengabdian kepada masyarakat ini dilakukan di Desa Kebonsari Kecamatan Candi Kabupaten Sidoarjo selama 2 bulan. Peternak yang diundang untuk mengikuti kegiatan tutorial dan peragaan inseminasi buatan itik sebanyak 32 orang, namun yang hadir dan aktif mengikuti kegiatan dan dapat dievaluasi dari pelaksanaan kegiatan ini berjumlah 19 orang. Karakteristik peternak saat dilaksanakan pengabidan pada masyarkat disajikan pada Tabel 1 sampai dengan Tabel 5.

TABEL I

UMUR PETERNAK YANG DISERTAKAN DALAM TUTORIAL DAN PERAGAANIB PADA ITIK

\begin{tabular}{|c|c|c|}
\hline Rentang umur / tahun & Frekuensi & Persentase / \% \\
\hline $20-30$ & 3 & 15,79 \\
\hline $31-40$ & 8 & 42,10 \\
\hline $41-50$ & 6 & 31,58 \\
\hline$>50$ & 2 & 10,53 \\
\hline Jumlah & 19 & 100 \\
\hline
\end{tabular}

TABEL II

PEKERJAAN PETERNAK YANG DISERTAKAN DALAM TUTORIAL DAN PERAGAANIB PADA ITIK

\begin{tabular}{|c|c|c|}
\hline Pekerjaan & Frekuensi & Persentase / \% \\
\hline Tani / nelayan & 1 & 5,26 \\
\hline PNS & 1 & 5,26 \\
\hline Wirausaha & 16 & 84,21 \\
\hline Pegawai swata & 1 & 5,26 \\
\hline Jumlah & 19 & 100 \\
\hline
\end{tabular}

TABEL III

PENDIDIKAN PETERNAK YANG DISERTAKAN DALAM DALAM TUTORIAL DANPERAGAAN IB PADA ITIK

\begin{tabular}{|c|c|c|}
\hline Pendidikan & Frekuensi & Persentase / \% \\
\hline Sekolah Dasar & 7 & 36,84 \\
\hline Sekolah lanjutan pertama & 5 & 26,32 \\
\hline Sekolah menengah umum & 5 & 26,32 \\
\hline
\end{tabular}

\begin{tabular}{|c|c|c|}
\hline Perguruan tinggi & 2 & 10,53 \\
\hline Jumlah & 19 & 100 \\
\hline
\end{tabular}

TABEL IV

PERSENTASE PETERNAK DALAM MENGIKUTI TUTORIAL DAN PERAGAANIB ITIK SEBELUMNYA

\begin{tabular}{|c|c|c|}
\hline & Frekuensi & Persentase / \% \\
\hline Sudah & 5 & 26,32 \\
\hline Belum & 14 & 73,68 \\
\hline Jumlah & 19 & 100 \\
\hline
\end{tabular}

TABEL V

LAMA PETERNAK DALAM BETERNAK ITIK

\begin{tabular}{|c|c|c|}
\hline Rentang umur / tahun & Frekuensi & Persentase / \% \\
\hline $1-5$ & 8 & 42,10 \\
\hline $6-10$ & 7 & 36,84 \\
\hline $11-15$ & 4 & 21,05 \\
\hline Jumlah & 19 & 100 \\
\hline
\end{tabular}

Setelah dilakukan pelatihan tutorial dan peragaan inseminasi buatan itik dan dilakukan evaluasi kemampuan peternak didapat peningkatan kemampuan peternak sebesar 14,74\% seperti yang disajikan dalam Tabel 6. Peningkatan ini didapat dari evaluasi dalam menjawab pertanyaan secara kuisioner dengan benar baik sebelum pelatihan dan setelah pelatihan selesai.

TABEL VI

LAMA PETERNAK DALAM BETERNAK ITIK

\begin{tabular}{|c|c|c|}
\hline & Frekuensi & Persentase / \% \\
\hline Sebelum & 16 & 16,84 \\
\hline Sesudah & 30 & 31,58 \\
\hline Kenaikan & 14 & 14,74 \\
\hline
\end{tabular}

\section{A. Respon Pengetahuan Responden Setelah Pemberdayaan}

Dari hasil wawancara pada saat awal kegiatan IPTEKS dilaksanakan dapat diketahui bahwa sebagian besar peternak itik Kelompok Peternak Itik Desa Kebonsari Kecamatan Candi Sidoarjo tidak memahami bahwa perkembangbiakan atau perkawinan itik jantan dengan itik betina dapat dilakukan tidak dengan cara kawin alam. Sebagian besar responden belum mengenal teknologi kawin suntik atau Inseminasi Buatan (IB) pada ternak itik. 
Mereka beranggapan bahwa itik dapat bertelur karena hasil kawin alam saja.

Setelah dilakukan penyuluhan dan pelatihan tampak pengetahuan peternak itik tentang penggunaan teknologi IB meningkat. Pada akhirnya mereka memahami bahwa dengan menerapkan teknologi IB memberikan harapan percepatan peningkatan produksi itik, efisiensi penggunaan pejantan dan bibit pejantan lebih berkualitas. Hal ini dapat terjadi dikarenakan aplikasi pelaksanaan IB pada itik dapat dilaksanakan ditingkat peternak itik dengan peralatan yang sederhana dan mudah diperoleh serta pelaksanaan tidak memerlukan biaya yang banyak..

\section{B. Respon Kemampuan Responden Dalam Penerapan IB pada Itik}

Dari hasil wawancara pada saat awal kegiatan IPTEKS dilaksanakan dapat diketahui bahwa sebagian besar peternak itik Kelompok Peternak Itik Desa Kebonsari Kecamatan Candi Sidoarjo tidak memahami bahwa perkembangbiakan atau perkawinan itik jantan dengan itik betina dapat dilakukan tidak dengan cara kawin alam. Sebagian besar responden belum mengenal teknologi kawin suntik atau Inseminasi Buatan (IB) pada ternak itik. Mereka beranggapan bahwa itik dapat bertelur karena hasil kawin alam saja.

\section{Respon Minat Responden Dalam Penerapan IB pada itik}

Sebagian besar responden peserta atau peternak itik berminat $(73,68 \%)$ menerapkan sistem perkawinan itiknya menggunakan teknologi IB, sedangkan sebagian kecil responden tidak berminat.

Adanya harapan peningkatan mutu, daya tetas, fertilitas dan kualitas anak itik serta efisiensi pemeliharaan pejantan itik dengan cara menerapkan IB pada itik yang dipelihara merupakan alasan yang dikemukakan oleh responden yang berminat, sebagian responden ingin memanfaatkan waktu luangnya untuk memperoleh hasil tetas yang lebih baik dengan jumlah yang banyak. Bagi responden yang tidak berminat, mengemukakan alasan tidak punya banyak waktu luang dan tidak ingin membuat IB itik sebagai pekerjaan sambilan dengan alasan pemasaran belum jelas.

TABEL VII

PERSENTASE PETERNAK YANG BERMINAT DALAM MENGEMBANGKAN DIMASA YANG AKAN DATANG SETELAH MENGIKUTI PELATIHAN TUTORIAL DAN PERAGAAN IB PADA ITIK

\begin{tabular}{ccc}
\hline Respon minat & Frekuensi & Persentase /\% \\
\hline Ya & 11 & 57,89 \\
Cukup & 3 & 15,79 \\
Kurang & 1 & 5,26 \\
Tidak & 4 & 21,05 \\
\hline
\end{tabular}

\begin{tabular}{lll}
\hline Jumlah & 19 & 100 \\
\hline
\end{tabular}

Responden yang mau berusaha menerapkan program IB itik dikarenakan mereka sangat mudah menerima inovasi baru tentang manfaatkan teknologi IB pada itik. Dengan meningkatnya pengetahuan seseorang maka keinginan maju dan mengembangkan diri sema $\neg$ kin meningkat. Mereka bersedia meluangkan waktunya untuk hal-hal yang dapat memberikan harapan lebih baik dimasa depan dengan adanya penambahan pendapatan. Makin tinggi kesempatan untuk menerima inovasi baru, maka kemauan untuk memajukan usaha semakin besar [8].

\section{Hambatan Pengembangan Penerapan IB pada itik}

Usaha penerapan IB pada itik di Kelompok Peternak Itik Desa Kebonsari Kecamatan Candi Sidoarjo menghadapi hambatan masih belum memasyaraktnya teknologi IB itik. Di samping itu sebagian peternak menganggap kurang mantap dan puas bila itik yang dipelihara tidak itik jantan yang mendampingi itik betina. Sementara itu teknologi IB itik ini mudah dilakukan dan layak untuk dikembangkan didaerah Desa Kebonsari Kecamatan Candi Sidoarjo karena sesuai dengan karak $\neg$ teristik usaha masyarakat sebagai peternak itik. Didukung adanya minat dari peternak dan ketersediaan serta motivasi untuk efisiensi usaha sehingga diperoleh keuntungan usaha yang meningkat. Kendala yang dihadapi dapat diatasi dengan cara pemersatuan peternak itik untuk menerapkan teknologi IB pada itik untuk perkembangbiakan itik dengan hasil fertilitas dan daya tetas yang lebih meningkat.

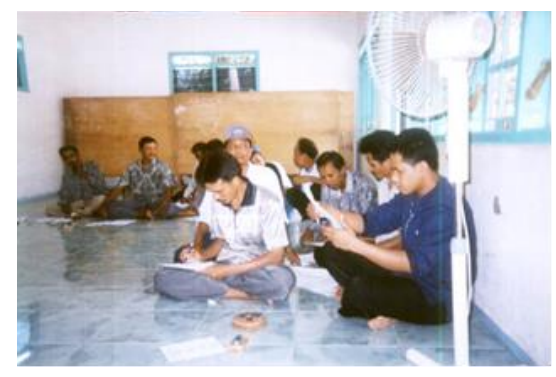

Gambar 1. Contoh gambar dengan resolusi yang tidak dapat diterima

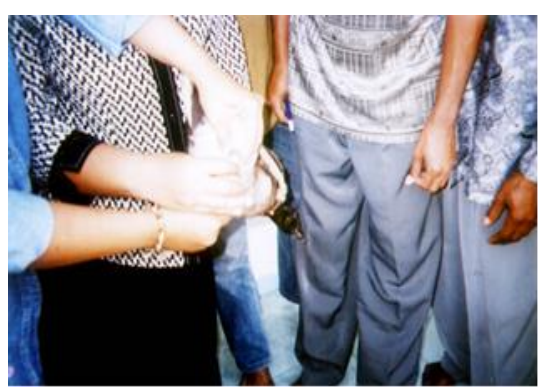

Gambar 2. Penekanan pada cloaca itik untuk mengeluarkan alat kelamin jantan hingga dilakukan koleksi spermatozoa 


\section{KESIMPULAN DAN SARAN}

A. Kesimpulan

Setelah dilakukan penerapan IPTEKS teknologi

IB pada itik dapat disimpulkan

1. Pemberdayaan melalui penyuluhan dan pelatihan telah mampu meningkatkan pengetahuan dan kemampuan peternak itik di Kelompok Peternak Itik Desa Kebonsari Kecamatan Candi Sidoarjo sebesar 14,74\%.

2. Sebagian besar peternak itik $(73,68 \%)$ berminat menerapkan teknologi IB pada itik sebagai upaya efisiensi penggunaan pejantan itik, meningkatkan fertilitas dan daya serta kualitas anak itik dalam rangka meningkatkan pendapatan.

B. Saran

Saran yang dapat dikemukakan dengan adanya penerapan IPTEKS teknologi IB pada itik adalah:

1. Semakin diperbanyak kelompok peternak itik untuk menerapkan teknologi IB pada itik.

2. Promo lebih luas keluar daerah untuk mengenalkan program IB itik pada kelompok lain.

3. Perlu partisipasi dan keterlibatan secara aktif perbankan dan pemerintah daerah dalam pemberian kredit untuk pengadaan sarana produksi dan pembinaan anggota serta pemasaran anak itik.

\section{DAFTAR PUSTAKA}

[1] Setioko, A.R. 2012. Teknologi Inseminasi Buatan untuk Meningkatjan Produktivitas Itik Hibrida Aerati sebagai penghasil daging Pengembangan Inovasi Pertanian 5(2), 2012: 108-123

[2] Toelihere, M.R. 1979. Inseminasi Buatan pada Ternak. Penerbit Angkasa, Bandung.

Hafez, E.S.E. 1983. Reproduction in Farm Animals. Lea Fabiger, Philadelphia.

[3] Watanabe, M. 1961. Experimental studieson the artificial insemination of domestic duck with special referenceto the productioin of mule-ducks. J.Fac. Fish. Anim. Husb. 3(2): 439-478

[4] Huang, H.H. and T. C. Chow. 1974. Artificialinsemination in mule duck production.p. 261-262. Proc. XV World PoultryCongress, New Orleans, Washington,DC, the United States of America.

[5] Ditjennak (Direktorat Jenderal Peternakan). 2010. Statistik Peternakan 2010.Direktorat Jenderal Peternakan, Jakarta.

[6] Siagian, S. P. 2015. Manajemen Sumber Daya Manusia. Jakarta: Bumi Aksara

[7] Wibowo. (2013). Manajemen Kinerja. Jakarta: Rajawali Pers 